\title{
CrimRxiv
}

\section{Protect, Serve, and Deport: The Rise of Policing as Immigration Enforcement}

\section{Amada Armenta}

Published on: Jun 27, 2017

DOI: $10.21428 / \mathrm{cb} 6 \mathrm{ab} 371.4 \mathrm{f} 87 \mathrm{~d} 196$

License: Creative Commons Attribution 4.0 International License(CC-BY 4.0). 
